\title{
PALAEONTOLOGICAL (RADIOLARIAN) LATE JURASSIC AGE CONSTRAINT FOR THE STEPANAVAN OPHIOLITE (LESSER CAUCASUS, ARMENIA)
}

\author{
Danelian T. ${ }^{1}$, Galoyan G. ${ }^{2,3}$, Rolland Y. ${ }^{2}$, and Sosson M. ${ }^{2}$ \\ ${ }^{1}$ Université Pierre-et-Marie-Curie, UMR 5143, Micropaléontologie, C. 104, 4 place Jussieu, \\ 75005 Paris, France danelian@ccr.jussieu.fr \\ ${ }^{2}$ Laboratoire Géosciences AZUR., Université de Nice Sophia Antipolis Parc Valrose, 28 Avenue \\ de Valrose, 06108 Nice Cedex 2, France \\ ${ }^{3}$ Institute of Geological Sciences, National Academy of Sciences of Armenia, 24a Baghramian \\ avenue, Yerevan, 375019 Armenia
}

\begin{abstract}
Micropalaeontological age evidence for the sedimentary cover of ophiolites is important to understand the palaeogeographic and geodynamic evolution of Tethyan realms. The Stepanavan ophiolitic suite of Northern Armenia consists of peridotites, gabbros, plagiogranite and lavas with a radiolarite sedimentary cover. It is regarded as the northern extension of the Sevan-Akera ophiolitic zone and may be considered as the eastern extension of the Izmir-Ankara suture zone. It represents the relics of a slow-spreading mid-oceanic ridge that was active between Eurasia and the South-Armenian Block of Gondwanian origin. Radiolaria extracted from radiolarites of the Stepanavan ophiolite provide for the first time a Late Jurassic (late Kimmeridgian to early Tithonian) age constraint for this part of Tethyan oceanic crust preserved in Lesser Caucasus.
\end{abstract}

Key words: Tethys, radiolarites, Mesozoic, Late Jurassic, Caucasus.

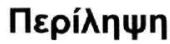

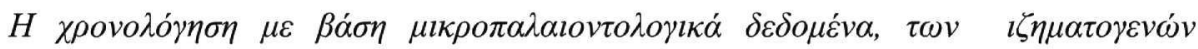

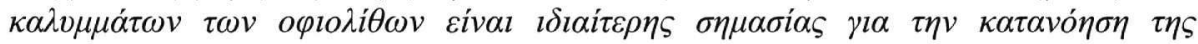



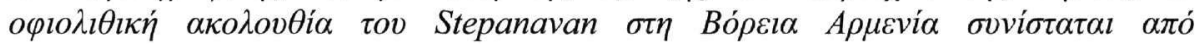

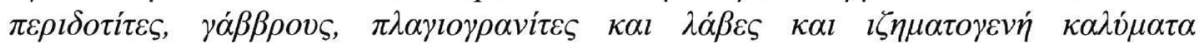

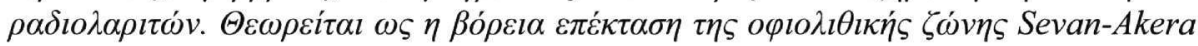





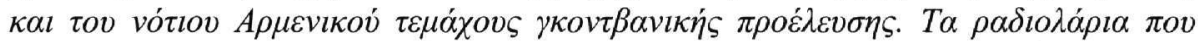

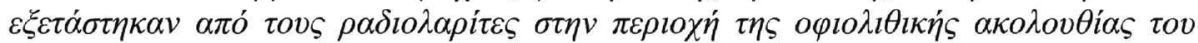

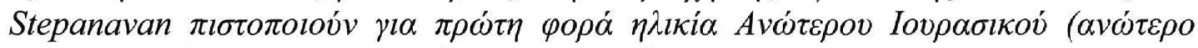

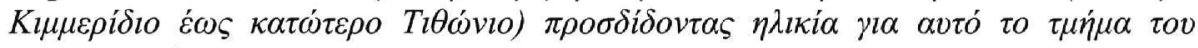

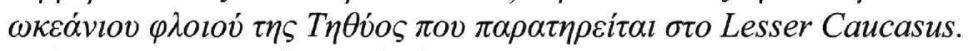

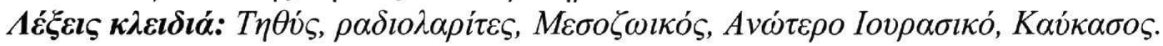




\section{Introduction}

The geological history of ophiolite units in Armenia (Lesser Caucasus) is linked to the evolution of the Tethys ocean (Dercourt et al. 1986). Radiolarian biochronology has had an enormous impact the last twenty years in unravelling the geodynamic evolution of Tethyan oceanic realms and continental margins (De Wever \& Dercourt 1985, De Wever et al. 1994, Danelian and Robertson 1997, 2001, Danelian et al. 2006). The micropalaeontological dating of the siliceous sedimentary cover of ophiolitic lavas are important to constrain the timing of opening, quiescence and closure of parts of Tethys ocean. Dating radiolarites overlying ancient oceanic crust preserved in Armenia is of much importance for our understanding of the geodynamic evolution of the greater area between Eurasia and the South-Armenian Block (Fig. 1) that originated from Gondwana (Knipper 1975, Knipper and Khain 1980).

Here we will present the first radiolarian evidence for the Stepanavan ophiolite unit, which is part of the Lesser Caucasus ophiolite belt, striking E-W in north Armenia (Fig. 2; Aslanyan 1958, Gabrielyan 1959). We will conclude by discussing the implications of this palaeontological evidence for the evolution of the Mesozoic Tethys in Armenia.

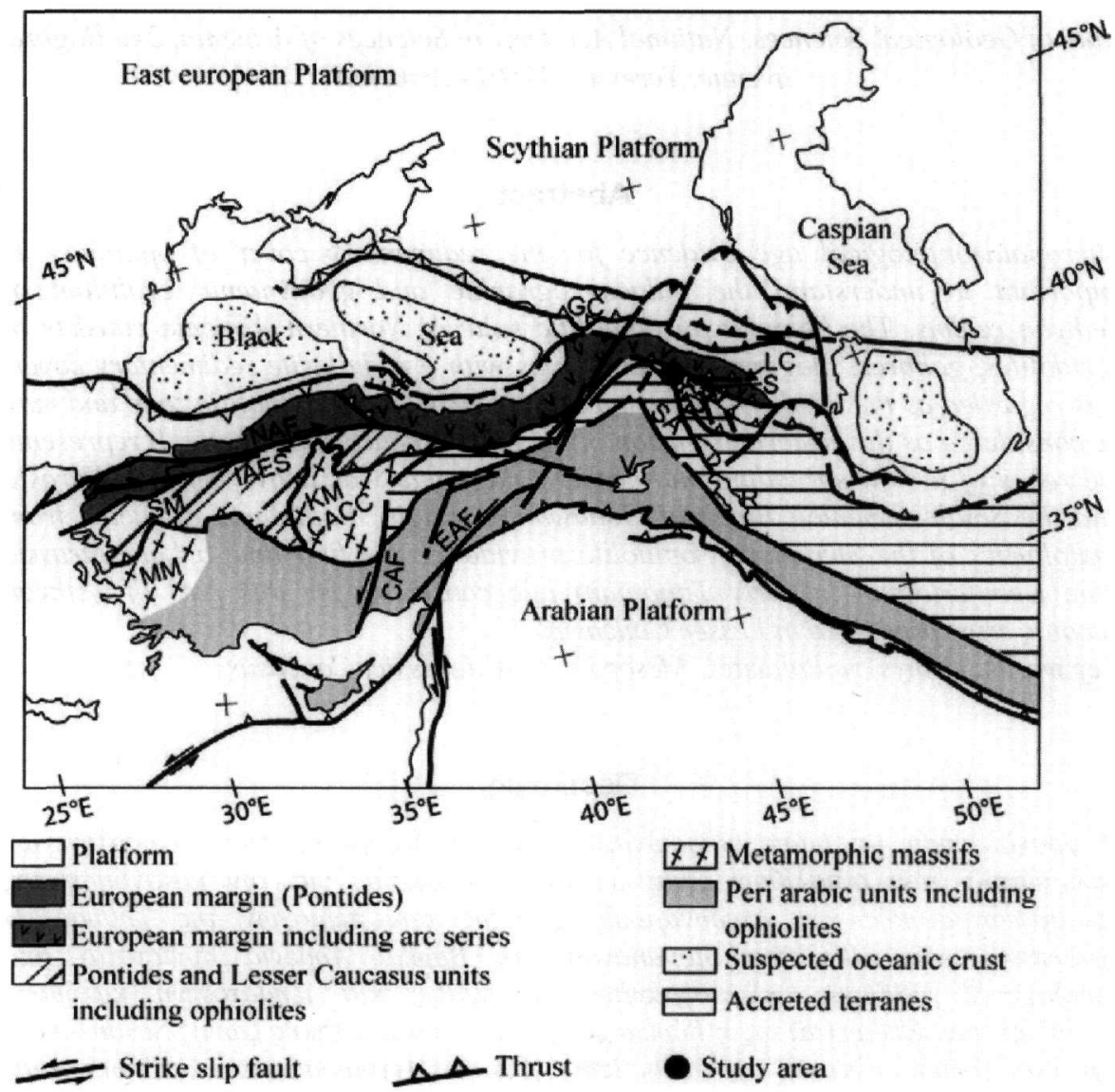

Figure 1 - Structural map of the Arabia-Eurasia collision area, after Avagyan et al. (2005).

CACC: Central Anatolian Crystalline Complex, KM: Kirsehir Massif, MM: Menderes

Massif, SM: Sakarya Massif, IAES : Izmir-Ankara-Erzinchan Suture, NAF : North Anatolian Fault, EAF : East Anatolian Fault, GC : Great Caucasus, LC: Lesser Caucasus, SA: South-Armenian Block, V: Van Lake, S: Sevan Lake, R: Reziyeh Lake 


\section{Geological setting}

Three ophiolite zones are recognized in Armenia (Fig. 2):

1) Sevan-Akera zone, situated in the east and south-east of Lake Sevan, and including the Amassia Stepanavan ophiolites (northwestern part of the Sevan-Akera zone),

2) Vedi, a relatively small outcrop of ophiolitic rocks in the south-east of Yerevan,

3) Zangezur ophiolites, in the southeastern part of the country.



Figure 2 - Geological map of Armenia, showing locations of ophiolitic complexes and of the study area.

Previous work (Aghamalyan 1978) and new structural field observations and cartography southwest of the city of Stepanavan show that a blueschists unit appears in small $\left(\sim 2 \mathrm{~km}^{2}\right.$-scale $)$ tectonic windows below epidote-amphibolite facies meta-ophiolites. The latter constitutes the tectonic sole of an unmetamorphosed ophiolitic suite covered unconformably by brown siltstones and limestones. The latter passes laterally to pillow lava flows and volcanic tuffs covered uncomfortably in their turn by acidic volcanic rocks assumed of Middle to Upper Eocene age (Figs $3,4)$.

The ophiolitic sequence is formed by serpentinized peridotites (lherzolites, wehrlites and websterites) cross-cut by small (100 m-large) intrusive bodies, the composition of which evolved from wehrlites to laminated gabbros and plagiogranites. It is likely that these deep plutonic parts were exposed on the sea-floor and consequently hydrothermalized (occurrence of "listwenites"). They are unconformably overlain by doleritic pillow lavas and radiolarites. Lava flows are scattered, and it is not rare to observe serpentinized peridotites overlain by radiolarites. Diabasic dikes occur also very scarcely. 


\section{Results}

Two radiolarian chert samples (Ar03-51 and 53; Fig. 3) were processed in the laboratory following the hydrofluoric acid treatment described by Pessagno and Newport (1970) and Dumitrica (1970). Only one of them (Sample Ar 03-51) yielded a moderately well-preserved radiolarian assemblage following successive leaching with low concentration acid (HF $4 \%$ ).

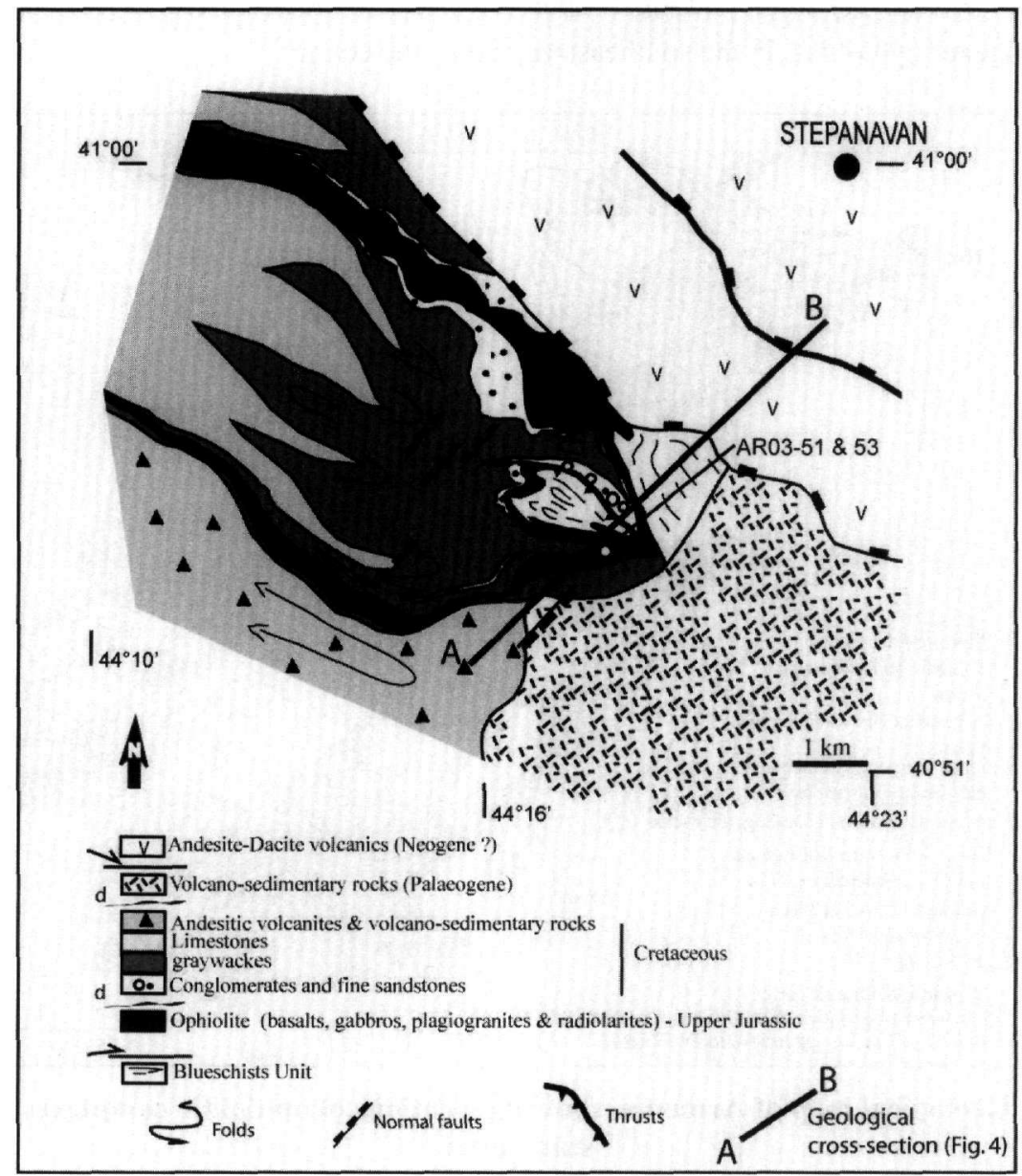

Figure 3 - Simplified geolological map of the Stepanavan ophiolitic complex, with location of the studied samples

Identifiable Radiolaria include the following taxa:

Acanthocircus trizonalis ssp.cf. A.t.angustus Baumgartner

Acanthocircus trizonalis trizonalis (Rüst)

Archaeodictyomitra sp.

Cinguloturris carpatica Dumitrica

Emiluvia sp.

Mirifusus dianae (Karrer) s.l.

Podocapsa amphitreptera Foreman

Ristola altissima (Rüst) s.l.

Sethocapsa simplex Taketani 


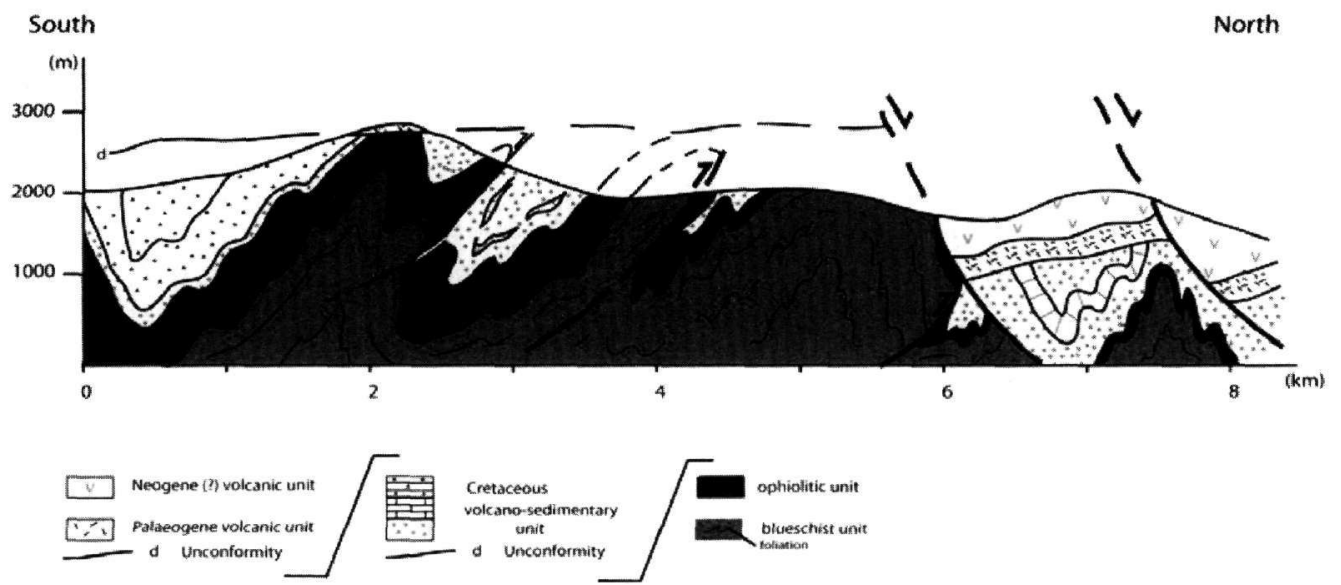

Figure 4 - Simplified geolological section of the Stepanavan ophiolitic complex (see Fig. 3 for its emplacement)

Age-diagnostic Radiolarian species are illustrated in Fig. 5. The assemblage can be correlated with Unitary Association Zones (UAZ) 9 to 11 (mid/late Oxfordian to late Kimmeridgian/early Tithonian) of the biozonation by Baumgartner et al. (1995). This is based on the co-occurrence of species Ristola altissima (Rüst) s.l. (Fig. 5a), Cinguloturris carpatica Dumitrica (Fig. 5b) and Podocapsa amphitreptera Foreman (Fig. 5c). Acanthocircus trizonalis angustus Baumgartner (Fig. $5 \mathrm{~d}$ ) is for the moment identified with some doubts because of its poor preservation. If the presence of this subspecies is confirmed in the future, the age could be restricted to UAZ 9-10 (mid/late Oxfordian to late Oxfordian/early Kimmeridgian).

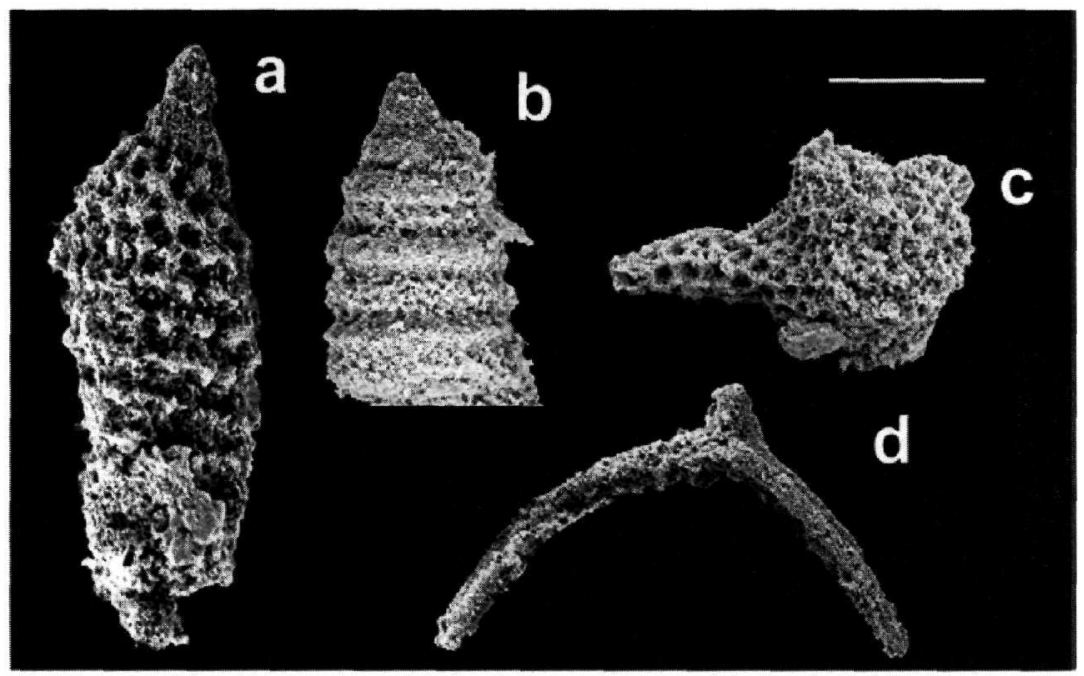

Figure 5 - Scanning electron microphotographs of Radiolaria yielded from sample Ar03/51. Bar scale is common to all species and corresponds to $100 \mu \mathrm{m}$. a) Ristola altissima s.l.; b) Cinguloturris carpatica; c) Podocapsa amphitreptera; d) Acanthocircus trizonalis ssp. cf. $A$. $t$. angustus

\section{Discussion}

The age of Armenian ophiolites is of great importance for understanding the palaeogeographic and geodynamic evolution of the Tethys in Caucasus and for lateral correlations of Tethyan ophiolitic belts in the Middle East. 
Previous studies on radiolaria yielded from radiolarites intercalated or overlying ophiolitic lavas from the Sevan zone (Pechaniz river outcrop) pointed to a Late Jurassic-Neocomian age. More particularly, various Lower Cretaceous intervals were recognized, while the presence of Upper Jurassic deposits remained questionable (Zakariadze et al. 1983). Although Lower and Middle Jurassic radiolarites appear to exist in Armenia, they seem to be unrelated to ophiolites (Vishnevskaya 1995). More recently, Knipper et al. (1997) established the presence of Late Triassic (Carnian) and Early Jurassic (Toarcian) radiolaria in cherts intercalated with ophiolitic breccias in the Zod pass area south-east of Lake Sevan.

The micropalaeontological data presented here provide the first firm evidence for a Late Jurassic formation of Tethyan oceanic crust between the active Eurasian margin (to the North) and the South-Armenian Block (in the South), a microcontinent detached from Gondwana during the Late Palaeozoic -Early Mesozoic time. More particularly, the Stepanavan ophiolite is regarded as part of a slow spreading oceanic ridge that was formed in a back arc position (Galoyan et al. submitted).

The Stepanavan ophiolite is considered as the extension to the North of the Sevan-Akera ophiolitic zone and it might be related with the Khoy ophiolite in northern Iran. It also appears to represent an eastern extension of the Anatolian or Izmir-Ankara ophiolitic suture zone (Knipper 1975, Adamia et al. 1980), in which the presence of Jurassic, but also Upper Triassic and Lower Cretaceous radiolarites intercalated with ophiolitic lavas were recently documented (Göncüoğlu et al. 2000, Tekin et al. 2002).

\section{Acknowledgments}

Funding from the Middle East Basins Evolution (MEBE) project is gratefully acknowledged. Fieldwork was greatly facilitated by the support of the Institute of Geological Sciences of Armenian Academy of Science. This study would not be possibly completed without the travelling funds provided by the French Embassy in Armenia and the French Ministry for Foreign Affairs (ECO-NET program). Constructive remarks by A. Matsuoka (Niigata, Japan) improved the initial manuscript.

\section{References}

Adamia, Sh., Bergougnan, H., Fourquin, C., Haghipour, A., Lordkipanidze, M., Ozgül, N., Ricou, L., and Zakariadze, G., 1980. The Alpine Middle East between the Aegean and the Oman traverses, $26^{\text {th }}$ International Geololgical Congress, Paris, C5, 122-136.

Aghamalian, V.A., 1978. The old metamorphic complexes of the territory of Armenian SSR and their tectonic disposition, Proc. Second Regional Petrographic Symposium on Caucasus, Crime and Carpathians, Tbilisi, 109-115.

Aslanyan, A.T., 1958. The Regional Geology of Armenia. Izd.'Haypethrat', Yerevan. (in Russian)

Avagyan, A., Sosson, M., Philip, H., Karakhanian, A., Rolland, Y.A., Melkonyan, R., Rebai, S., and Davtyan, V., 2005. Neogene to Quaternary stress field evolution in Lesser Caucasus and adjacent regions using fault kinematics analysis and volcanic cluster data, Geodinamica Acta 18, 401-416.

Baumgartner P.O., Bartolini A., Carter E.S., Conti M., Cortese G., Danelian T., De Wever P., Dumitrica P., Dumitrica-Jud R., Gorican S., Guex J., Hull D.M., Kito N., Marcucci M., Matsuoka A., Murchey B., O’Dogherty L., Savary J., Vishnevskaya V., Widz D., and Yao A., 1995. Middle Jurassic to Early Cretaceous Radiolarian Biochronology of Tethys based on Unitary Associations, In Baumgartner et al. (eds), Middle Jurassic to Lower 
Cretaceous Radiolaria of Tethys: Occurrences, Systematics, Biochronology, Mém. Géol. (Lausanne), 23, 1013-1048pp.

Danelian, T., and Robertson, A.H.F., 1997. Radiolarian evidence for the stratigraphy and palaeooceanography of the deep-water northern passive margin of the Indian plate (Karamba Formation, Indus Suture Zone, Ladakh Himalaya), Mar. Micropal. 30 (1-3), 171-195.

Danelian, T., and Robertson, 2001. Neotethyan evolution of eastern Greece (Pagondas Mélange, Evia island) inferred from radiolarian biostratigraphy and the geochemistry of associated extrusive rocks, Geological Magazine, 138, 245-363.

Danelian, T., Robertson, A.H.F., Collins, A., and Poisson, A., 2006. Biochronology of Jurassic and Early Cretaceous radiolarites from the Lycian Mélange (SW Turkey) and implications for the evolution of the Northern Neotethyan ocean. In A.H.F. Robertson and D. Mountrakis (eds), Tectonic Development of the Eastern Mediterranean Region, Geological Society, London, Special Publications 260, 229-236.

Dercourt, J., Zonenshain, L.P., Ricou, L.E., Kazmin, V.G., Le Pichon, X., Knipper, A.L., Grandjacquet, C., Perchersky, D.H., Boulin, J., Sibuet, J.C., Savostin, L.A., Sorokhtin, O., Westphal, M., Bashrov, M.L., Lauer, J.P., and Biju-Duval, B., 1986. Geological evolution of the Tethys belt from the Atlantic to the Pamirs since the Lias, Tectonophysics, 123, 241315.

De Wever, P., and Dercourt, J., 1985. Les radiolaires triasico-jurassiques marquers stratigraphiques et paléogéographiques dans les chaînes alpines périméditerranéennes: une revue, Bull. Soc. Géol. France, 8, I, 5, 653-662.

De Wever, P., Azéma, J., and Fourcade, E., 1994. Radiolaires et Radiolarites: production primaire, diagenèse et paléogéographie, Bull. Centres Rech. Explor.-Prod. Elf Aquitaine, 18(1), 315379 .

Dumitrica, P., 1970. Cryptocephalic and cryptothoracic Nasselaria in some Mesozoic deposits of Romania, Rev. Roum. Géol. Géophys. Géogr., Sér. Géol., 14, 45-124.

Gabrielyan, A.A., 1959. The main questions about Armenian Tectonics, Izd. NAS SSR Armenia. (in Russian)

Galoyan, G., Rolland, Y., Sosson, M., Corsini, M., and Melkonyan, R., submitted. Evidence for superposed MORB, oceanic plateau and volcanic arc series in the Lesser Caucasus (Stepanavan, Armenia). C.R. Geoscience.

Göncüoğlu, M.C., Turhan, N., Sentürk, K., Ozcan, A., Uysal, S., and Yalmiz, K., 2000. A geotraverse across northwestern Turkey: tectonic units of the Central Sakarya region and their tectonic evolution. In E. Bozkurt, J.A. Winchester and J.D.A. Piper (Eds), Tectonics and Magmatism in Turkey and the surrounding area. Geological Society, London, Special Publication 173, 139-161.

Knipper, A.L., 1975. The oceanic crust in the alpine belt, Tr. GIN NAS USSR, Edition 267, 207p. (in Russian)

Knipper, A.L., and Khain, E.V., 1980. The structural position of ophiolites of the Caucasus, Ofioliti, Special Issue, 2, 297-314.

Knipper, A.L., Satian, M.A., and Bragin, N.Yu., 1997. Upper Triassic-Lower Jurassic Volcanogenic and Sedimentary Deposits of the Old Zod Pass (Transcaucasia), Stratigraphy, geological correlation, 3, 58-65. (in Russian)

Pessagno, Jr., E.A., and Newport, R.L., 1972. A technique for extracting Radiolaria from radiolarian cherts. Micropaleontology, 18(2), 231-234 
Tekin, U.K., Göncüoğlu, M.C., and Turhan, N., 2002. First evidence of Late Carnian radiolarians from the Izmir-Ankara suture complex, central Sakarya, Turkey: implications for the opening age of the Izmir-Ankara branch of Neo-Tethys, Geobios, 35, 127-135.

Zakariadze, G.S., Knipper, A.L., Sobolev, A.V., Tsamerian, O.P., Dmitriev, L.V., Vishnevskaya, V.S., and Kolesov, G.M., 1983. The ophiolite volcanic series of the Lesser Caucasus, Ofioliti, 8/3, 439-466.

Vishnevskaya, V., 1995. Jurassic-Lower Cretaceous radiolarians from the Caucasus and the Carpathians. In Baumgartner et al. (eds), Middle Jurassic to Lower Cretaceous Radiolaria of Tethys: Occurrences, Systematics, Biochronology, Mém. Géol. (Lausanne), 23, 915$921 \mathrm{pp}$. 